\title{
ANALYSIS OF GENETIC DIVERSITY FOR SOME GENETIC GROUPS AND COMPARING THEIR PRODUCTIVE PERFORMANCE IN CHICKENS
}

\author{
M.Y. Mahrous ${ }^{1}$; Lamiaa M. Radwan ${ }^{1}$ and M. E. El-denary ${ }^{2}$ \\ 1- Poultry Production Department, Faculty of Agriculture, Ain Shams University, Cairo, Egypt, 2- Genetics \\ Department, Faculty of Agriculture, Tanta University, Tanta, Egypt, Lamia radwan@agr.asu.edu.eg
}

Received: $4 / 3 / 2017$

\section{SUMMARY}

In the current study; genetic diversity and productive performance were estimated for some genetic groups: normally feathered (nanaff), frizzled feather (nanaFf), naked neck (Nanaff) and naked neck frizzled feather (NanaFf) ones. It seems that both $\mathrm{Na}$ and $\mathrm{F}$ genes play an important role in improving some economical traits such as: weight gain, feed conversion, live body weight, breast muscle percentage and edible parts percentage. The corresponding values for these traits were (598.65gm), (3.70), (1389.19gm), (11.14\%) and (73.39\%) for naked neck genotype (Nanaff), while it was (498.75gm), (3.90), (1315.42gm), (10.23\%) and (72.80\%) for nanaFf and (512.22gm), (3.73), (1410.21gm), (12.02\%) and (73.83\%) for naked neck with frizzled feather genotypes NanaFf ones when the comparison held with their normally feathered counterparts. Moreover; the naked neck (Na) gene decreased significantly abdominal fat percentage $0.48 \%$ for the Nanaff and $0.41 \%$ for NanaFf compared to normal feather (nanaff) genotype. The same trend was noticed for frizzled genotype, but it had a slight effect (0.09). Both Na and F genes improved meat production under the condition of this study._The similarity between genetic differences in this experiment appeared to be 80\%, 70\%, 90 and $70 \%$ for nanaff, Nanaff, nanaFf and NanaFf respectively. The degree of diversity or similarity within different genotypes reflected purity or identity of these categories. But, it is necessary to keep some variations between and within genotypes or breed to avoid the disadvantage of inbreeding.

Keywords: Chickens, carcass, frizzle, genetic diversity, naked neck

\section{INTRODUCTION}

In the recent years, climate changes led to an increase in the ambient temperature, resulting in misfortune economic losses. The high temperature causes high mortality percentage and also reduces some production traits in both broiler and laying stocks especially when the high temperature was accompanied with high relative humidity (Kgwatalala et al., 2012 and Khalid et al., 2012). It is well known that commercial strains, specialized in meat or egg production, were selected under environmental condition differed from that of hot climates. Their made commercial strains suffered from heat stress and their production of meat and egg was decreased. Commercial broiler strains suffered more from elevating temperature because these strains are heavy and have a high metabolic rate. The naked neck and frizzle genes are believed to improve adaptability in the tropics and hot climate, (Mahrous and Radwan 2011 and Liyanage et al., 2015) by increasing heat dissipation through decrease feather coverage. Also, these genes had a positive effects in improving economic traits such as growth rate and meat yield under high or moderate ambient temperatures (Matthew et al., 2011, Thutwa et al., 2012, Kgwatalala et al., 2013 and Dorji and Sunar, 2014). Ajayi et al. (2011); Rajkumar et al. (2011) and Radwan et al. (2015) studied the beneficial effects of naked neck and frizzled genes in improving the productive traits and immunity competence under heat conditions.

In 1978, day old chicks carried the mutation naked neck gene and it was imported from France. Since, this naked neck gene was introduced into local strains mainly Fayoumi. While, Zein El-Dein et al. (1981) studied the effect of Naked neck gene in improving the productive performance of both imported and local strains under Egyptian conditions. Several studies since 1981 was achieved to verify the obtained results about the effect of this gene $(\mathrm{Na})$ on improving growth rate and other productive traits. Radwan et al. (2015) measured immunity competence for these genotypes (normally feathered (nanaff), frizzled feather (nanaFf), naked neck (Nanaff) and naked neck frizzled feather (NanaFf) ones by using the specific microstallite studies and gene frequencies studies for egg production traits.

In the last few years, studies were more interested in using molecular genetics techniques in poultry breeding programs. These modern programs indicated a great importance in maintaining genetic variation within and between commercial lines and exotic populations. Also, RAPD and microstallites techniques were used in genomic mapping; identification of genes controlling productive traits and analyzing the degree of inbreeding; response to selection for stocks maintained under long-term selection programs and analyzing the genetic relationships among species at the molecular level 
(Heyen et al., 1999, Radwan 2014a\&b, and Oni et al., 2016). The present research was conducted to study the genetic diversity and some productive traits of four genetic groups.

\section{MATERIALS AND METHODS}

\section{Mating and management}

This experiment was carryed out at the poultry breeding farm, Faculty of Agriculture, Ain Shams University. The artificial insemination procedure was used to inseminate normally feathered females (nanaff) with the semen of heterozygous naked neck frizzled males (NanaFf). The obtained offspring was of four genetic groups; normally feathered (nanaff), frizzle feather ( nanaFf), naked neck (Nanaff) and naked neck frizzled feather (NanaFf). The naked neck and the frizzle genes are autosomal genes. The naked neck gene is an incompletely dominant once. It is easy to differentiate between homozygous and heterozygous genotypes by a tuft of feathers on the ventral side of the neck above the crop. The homozygous $(\mathrm{NaNa})$ genotype, either lack this tuft or it is reduced to a just few pin feathers or small feathers. While, homozygous frizzled birds, the edges of all feathers are extremely curved. These feathers are easily broken and therefore, the birds appear quite bare. The unmodified heterozygotes have the feather shafts and barbs of contour feathers curved, to a much lower extent than the homozygote (Fathi et al., 2013).

These genetic groups were winging-banded and brooded in electrical brooding batteries from hatching time and up to the end of the experiment (16 weeks of age) and were reared under similar environmental conditions. During the experimental period the degree of the recorded temperature ranged from $28.7^{\circ} \mathrm{C}$ to $32.5^{\circ} \mathrm{C}$.

\section{The studied traits}

Feed conservation and weight gain were recorded from the $8^{\text {th }}$ to $12^{\text {th }}$ weeks of age for males only from different groups. At the $12^{\text {th }}$ weeks of age, two hundred eighty males from all genotypes, 70 males from each genotype group used in this study were slaughtered after recording their live individual body weight. After dressing, the slaughtered birds were weighed and all the inedible parts were removed after recording their weights (intestines, proventriculus, gall bladder, spleen, esophagus and crop) and their percentage were calculated also. Giblets (heart, liver, gizzard) were cleaned and weighted to calculate their percentages. Abdominal fat was removed, weighted and its percentage was calculated. The breast muscles were weighed and their percentages were calculated.

\section{DNA extraction and purification}

Blood samples were collected, in EDTA tubes, from 10 individual males chosen randomly from each genotype group (nanaff, nanaFf, Nanaff and NanaFf). Then, these blood samples of each genotype group were mixed well. After this 3 samples from each mixture were taken to extract DNA (Bulk) by using Axygen Scientific kit, inc. USA Cat. No. AP-MNBL-GDNA-50. The primers used are listed in table 1. DNA were extracted for each genotype and grouped as follows: 1,2 and 3 for nanaff; 4,5 and 6 for Nanaff; 7,8 and 9 for nanaFf and 10,11 and 12 for NanaFf.

Table 1. Primer name, sequence and annealing temperature

\begin{tabular}{|c|c|c|}
\hline Primer name & Primer sequence & Annealing temp. \\
\hline ADL 115 & $\begin{array}{l}\text { F }\left(5^{-} \text {GGATGAGAAGAAAGGCA } 3^{-}\right) \\
\text {R }\left(5^{-} \text {CAATGGTGGTTCAGGTAATC } 3^{-}\right)\end{array}$ & $\begin{array}{l}50^{\circ} \mathrm{C} \\
56^{\circ} \mathrm{C}\end{array}$ \\
\hline ADL 209 & $\begin{array}{l}\text { F }\left(5^{-} \text {GGTTAGCTCCCTCCTTCCAG } 3^{-}\right) \\
\left.\text {R (5- AAGGAAACAAAGAGAAATCC } 3^{-}\right)\end{array}$ & $\begin{array}{l}63^{\circ} \mathrm{C} \\
52^{\circ} \mathrm{C}\end{array}$ \\
\hline ADL 231 & $\begin{array}{l}\mathrm{F}\left(5^{-} \text {ACTATTAGCCTGGGGAGAGC } 3^{-}\right) \\
\mathrm{R}\left(5^{-} \text {TCACTCCAGCTTGAGACAGG }\right. \\
\left.3^{-}\right)\end{array}$ & $\begin{array}{l}60^{\circ} \mathrm{C} \\
60^{\circ} \mathrm{C}\end{array}$ \\
\hline APH 23 & $\begin{array}{l}\text { F }\left(5^{-} \text {GGATGAGAAGAAGAAAGGCA } 3^{-}\right) \\
\left.\text {R ( } 5^{-} \text {AAGGAAACAAAGAGAAATCC } 3^{-}\right)\end{array}$ & $\begin{array}{l}56^{\circ} \mathrm{C} \\
52^{\circ} \mathrm{C}\end{array}$ \\
\hline APH 24 & $\begin{array}{l}\left.\text { F (5- GGATGAGAAGAAGAAAGGCA3 } 3^{-}\right) \\
\left.\text {R (5- CAATGGTGGTTCAGGTAATC } 3^{-}\right)\end{array}$ & $\begin{array}{l}56^{\circ} \mathrm{C} \\
56^{\circ} \mathrm{C}\end{array}$ \\
\hline A-03 & $5^{-}$AGTCAGCCA $3^{-}$ & $32^{\circ} \mathrm{C}$ \\
\hline B-03 & $5^{-}$CATCCCCCTG $3^{-}$ & $34^{\circ} \mathrm{C}$ \\
\hline G-03 & $5^{-}$GAGCCCTCCA $3^{-}$ & $34^{\circ} \mathrm{C}$ \\
\hline Z-03 & $5^{-}$CAGCACCGCA $3^{-}$ & $34^{\circ} \mathrm{C}$ \\
\hline
\end{tabular}

\section{Polymerase Chain Reaction (PCR) and amplification condition:}

PCR was performed in $25 \mu \mathrm{l}$ volumes containing $12 \mu 1$ of PCR Master mix (ROVALAB 2x Red PCR
Master Mix, Kantstr, Germany), $2 \mu$ of primer (10 $\mathrm{pmol} / \mu \mathrm{l}), 1 \mu \mathrm{l}$ genomic DNA $(50 \mathrm{ng} / \mu \mathrm{l})$ and $10 \mu \mathrm{l}$ sterile deionized water were added. Amplification was performed in a thermo cycler (Long Gene- 
MG96G/china) with the following temperature profiles: initial denaturation $95^{\circ} \mathrm{C}$ for $4 \mathrm{~min}, 35$ cycles (denaturatiom $95^{\circ} \mathrm{C} 1 \mathrm{~min} /$ annealing temp depending on the primer for $1 \mathrm{~min} /$ extension $72^{\circ} \mathrm{C} 1$ min) and Final extension $72^{\circ} \mathrm{C}$ for $5 \mathrm{~min}$. The reaction was hold at $4^{\circ} \mathrm{C}$.

\section{Statistical analysis:}

One-way analysis of variance was performed with a genotype effect. The statistical model could be described as follows: $Y i j=\mu+G_{i}+e_{i j}$.

Where; $\mu=$ overall mean, $G_{i}=$ genotypes effect and $\mathrm{e}_{\mathrm{ij}}=$ experimental error.

According to the General Linear Models (GLM) Procedure of SAS User's Guide, 2013.

\section{Analysis of the amplified DNA:}

The PCR product $(15 \mu \mathrm{l})$ was resolved by electrophoresis by using $2 \%$ agarose gel (supplemented with ethidium bromide) at $70 \mathrm{~V}$ for 90 min. DNA ladder (100 bp Larova GmbH / Germany) was used as DNA size markers. Gels were visualized with UV light and photographed by a Sony digital camera.

Similarity, diversity and relationships between genotypes were organized based on the similarity matrix established with neighbor joining (NJ) method using Jaccard formula $\mathrm{djk}=\mathrm{M} /(\mathrm{M}+\mathrm{N})$. Genetic similarity among chicken groups was estimated by scoring the presence and absence of bands produced by the primers. The presence (1) or absence (0) of a band of a particular molecular weight was scored as two alleles at a single locus. The NTSYSpc 2.01 software package was using present relationships between genotypes as dendogram (Rohlf, 1998).
Eventually, calculated percent polymorphism by using equation follow:

$$
\begin{array}{lll}
\begin{array}{l}
\text { Percent } \\
\text { polymorphism }
\end{array}= & \begin{array}{l}
\text { Total number of polymorphic } \\
\text { bands }
\end{array} & \mathrm{X} \\
& \text { Total number of bands } &
\end{array}
$$

\section{RESULTS AND DISCUSSION}

Feed conversion ratio and body weight gain of male chickens from different studied genotypes (nanaff, nanaFf, Nanaff, NanaFf) are shown in table 2. The naked neck gene (Nanaff) significantly increased weight gain by about $598.65 \mathrm{gm}$; frizzle gene (nanaFf) by about $498.75 \mathrm{gm}$ and naked neck frizzle feather by about $512.22 \mathrm{gm}$ compared to normal feather counter parts. On the other hand; the feed conservation was improved by about 0.25 (Nanaff); 0.05 (nanaFf) and 0.22 (NanaFf) when compared to normal feathers. The gene responsible for naked neck reduces the feather cover of birds and improve their heat tolerance and heat loss by radiation. This reflects on improving feed conversion under high temperature. As for, frizzle gene, it modifies the feather growth structure and this leads to curve outward cause facilitated bombard feather reason lower plumage coverage (Haaren-Kiso et al., 1994) . Alabi et al. (2012) and Hossain et al. (2012) recorded that naked neck gene improved thermoregulation, feed consumption, feed conservation and decrease body temperature under high $\left(30^{\circ} \mathrm{C}\right)$ or moderate $\left(22^{\circ} \mathrm{C}\right)$ ambient temperatures. Naked neck gene significantly improved feed conservation and body weight gain than the frizzle gene.

Table 2. Mean of feed conversion ratio and body weight gain of male birds from different studied

\begin{tabular}{|c|c|c|c|c|c|c|}
\hline \multirow[b]{2}{*}{ Traits } & \multicolumn{4}{|c|}{ Genotype } & \multirow[b]{2}{*}{ SEM } & \multirow[b]{2}{*}{ Prob } \\
\hline & nanaff & nanaFf & Nanaff & NanaFf & & \\
\hline Feed coversion (8-12) weeks & $3.95^{b}$ & $3.90^{\mathrm{b}}$ & $3.70^{\mathrm{a}}$ & $3.73^{\mathrm{a}}$ & 0.14 & 0.03 \\
\hline Body weight gain (8-12) weeks & $457.82^{c}$ & $498.75^{b}$ & $598.65^{\mathrm{a}}$ & $512.22^{\mathrm{ab}}$ & 40.12 & 0.01 \\
\hline
\end{tabular}
genotypes (nanaff, nanaFf, Nanaff, NanaFf)

${ }^{\mathrm{a}},{ }^{\mathrm{b}}$ and ${ }^{\mathrm{c}}$ Means within the same row, with different subscripts are significantly different $(\mathrm{P}<0.05)$,

NS = not significant

Carcass characteristics of male chickens are listed in table (3) for the different genetic groups handled in this study. It should be noted that both genes ( $\mathrm{Na}$ and F) caused a significant increase in live body weight, carcass percentage, breast muscle percentage and edible parts percentage, the corresponding value were $(1389.19 \mathrm{gm}),(69.02 \%),(11.14 \%)$ and $(73.39 \%)$ for Nanaff genotype and (1315.42gm), (68.35\%), $(10.23 \%)$ and $(72.80 \%)$ for nanaFf genotype and $(1410.21 \mathrm{gm}),(69.36 \%),(12.02 \%)$ and $(73.83 \%)$ for NanaFf genotype, respectively when compared to normal feather (nanaff) ones.

The naked neck gene (Nana) decreased plumage by about $20 \%$ (Mérat, 1990). This may be reflected on reducing the requirements from proteins. It may be directed to breast muscle growth and causing a significant increase in these muscles instead of plumage growth. So, it could be postulated that the naked neck gene plays an important role in increasing protein deposition in breast region and causing heavier breast muscles weights than that of the normal gene (REF).

Moreover; the naked neck gene significantly decreased abdominal fat percentage by 0.48 as shown in table (3). The same trend exist on the NanaFf genotype (0.41). While, the effect of $F$ gene alone on the same traits was very slight (it was $0.82 \%$ ) for nanaFf genotype and $(0.91 \%)$ for the nanaff genotype. The abdominal fat is considered an undesirable trait that decreases meat quality (Berri et 
al., 2005). Thus broiler strains are selected for reduced abdominal fat weight. The decrease in the abdominal fat, due to the naked neck gene, may be because of the energy for regulating body temperature for the limited feather covered.

Table 3. Mean of carcass characteristics of male chickens as affected by naked neck (Na), frizzled (F) and double segregation genes

\begin{tabular}{lllllll}
\hline & \multicolumn{9}{c}{ Genotype } & \\
\cline { 2 - 5 } Traits & nanaff & nanaFf & Nanaff & NanaFf & SEM & Prob \\
\hline Live body weight (gm) & $1297.86^{\mathrm{b}}$ & $1315.42^{\mathrm{b}}$ & $1389.19^{\mathrm{ab}}$ & $1410.21^{\mathrm{a}}$ & 90.12 & 0.0 \\
Carcass (\%) & $65.89^{\mathrm{b}}$ & $68.35^{\mathrm{a}}$ & $69.02^{\mathrm{a}}$ & $69.36^{\mathrm{a}}$ & 1.36 & 0.01 \\
Breast muscle (\%) & $10.01^{\mathrm{c}}$ & $10.23^{\mathrm{ab}}$ & $11.14^{\mathrm{b}}$ & $12.02^{\mathrm{a}}$ & 1.01 & 0.001 \\
Abdominal fat (\%) & $0.91^{\mathrm{a}}$ & $0.82^{\mathrm{a}}$ & $0.48^{\mathrm{b}}$ & $0.41^{\mathrm{b}}$ & 0.02 & 0.02 \\
Heart (\%) & 0.55 & 0.56 & 0.56 & 0.55 & 0.02 & $\mathrm{NS}$ \\
Liver (\%) & 1.85 & 1.93 & 1.89 & 1.91 & 0.14 & $\mathrm{NS}$ \\
Gizzard (\%) & 1.81 & 1.96 & 1.92 & 2.01 & 0.10 & $\mathrm{NS}$ \\
Giblets (\%) & 4.21 & 4.45 & 4.37 & 4.47 & 0.12 & NS \\
Edible parts (\%) & $70.10^{\mathrm{c}}$ & $72.80^{\mathrm{b}}$ & $73.39^{\mathrm{a}}$ & $73.83^{\mathrm{a}}$ & 1.86 & 0.01 \\
Inedible parts (\%) & $29.90^{\mathrm{a}}$ & $27.20^{\mathrm{ab}}$ & $26.61^{\mathrm{b}}$ & $26.17^{\mathrm{b}}$ & 2.013 & 0.01 \\
\hline
\end{tabular}

${ }^{a},{ }^{b}$ and ${ }^{\mathrm{c}}$ Means within the same row with different subscripts are significantly different $(\mathrm{P}<0.05)$,

$\mathrm{NS}=$ not significant

Clarification of the population structure of the different studied genotypes (nanaff, , Nanaff, nanaFf, and NanaFf) are shown in Figs. (1, 2, 3, 4 and 5). Degree of similarity within nanaff genotype reached $100 \%$ in sample number 1 . However, the similarities among this genotype (nanaff) reached approximately $95 \%$ and $90 \%$ in samples (2) and (3), respectively. While, degree of similarity within Nanaff genotype ranged from $60-70 \%$ as shown in Fig. (2). Also, Figs. (3 and 4) show that the degree of similarity reached $80 \%$ for nanaFf and NanaFf genotypes, respectively. The degree of similarity within different genotypes reflexes the degree of purity into these populations. A subdivision of the population was effected to relate fixation of alleles compared to the total population (Hartl, 1998). On the other hand, the degree of similarity between and within the different genetic groups is shown in Fig. (5). It appears that the similarity between the different genetic groups were $80 \%, 70 \%, 90$ and $70 \%$ for nanaff, Nanaff, nanaFf and NanaFf, respectively. Dorji and Sunar (2014) studied the relationship between Nigeria local breed, . which were posed the naked neck or frizzle genes and tried to classify them. As for the degree of similar they found that the normal plumage chickens occupied the first rank, followed by frizzled feather chickens while the naked neck or occupied by the latest order..

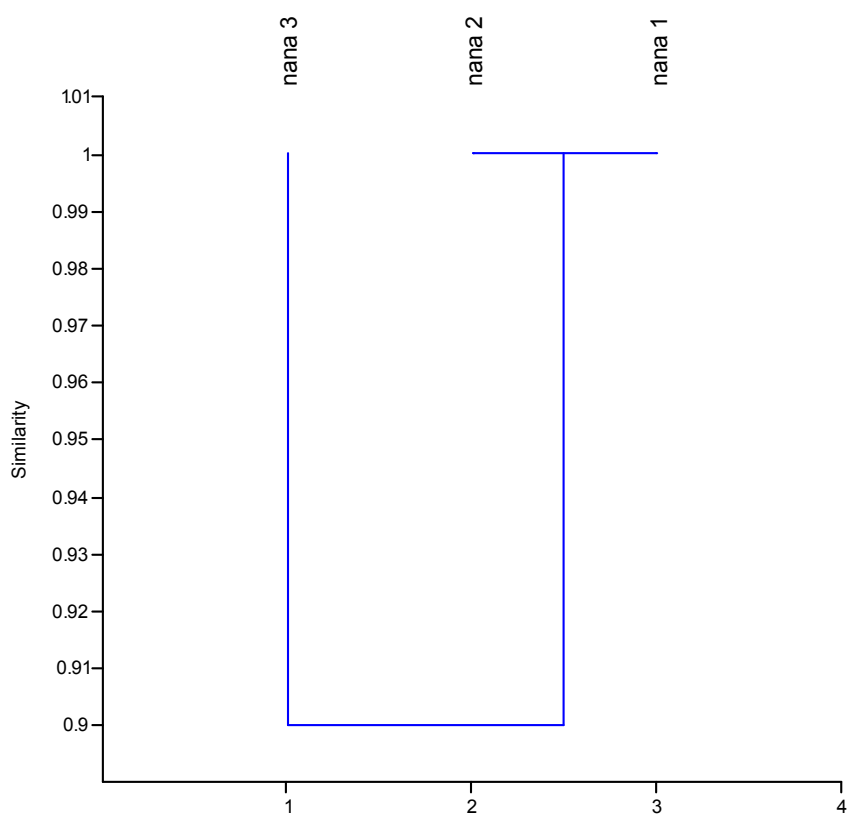

Fig.1. The degree of similarity within nanaff genotype. Blood samples collected from 10 males from nanaff genotype and mixed together, then 3 samples were taken dendogram of similarty 


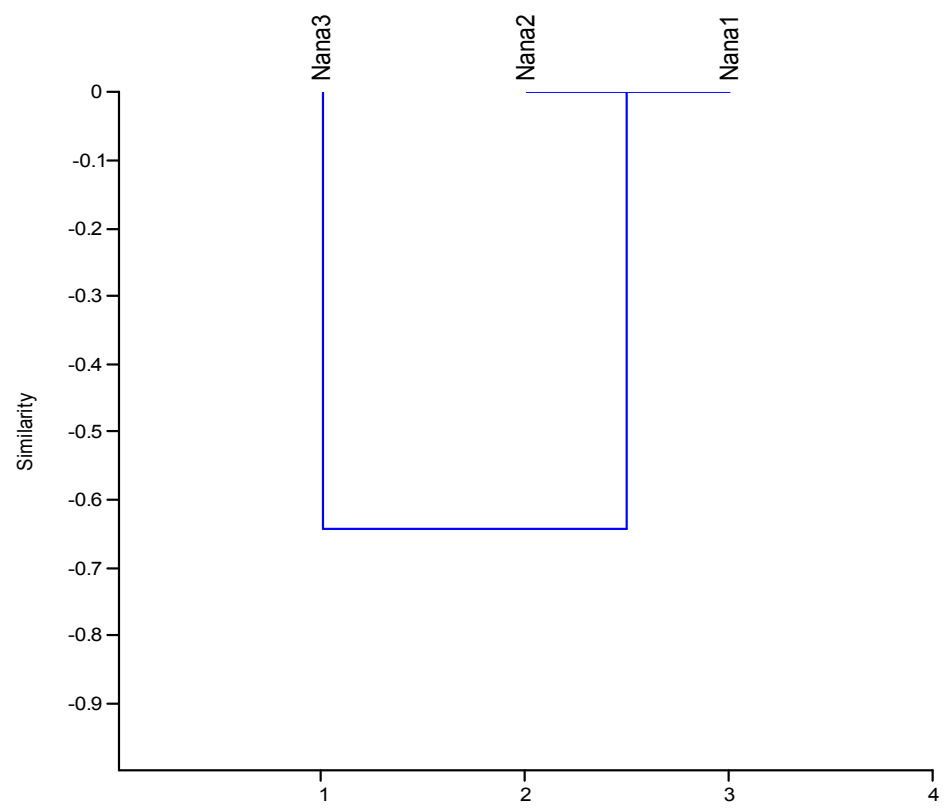

Fig. 2. The degree of similarity within Nanaff genotype. Blood samples collected from 10 males from Nanaff genotype and mixed together, then 3 samples were taken dendogram of similarty

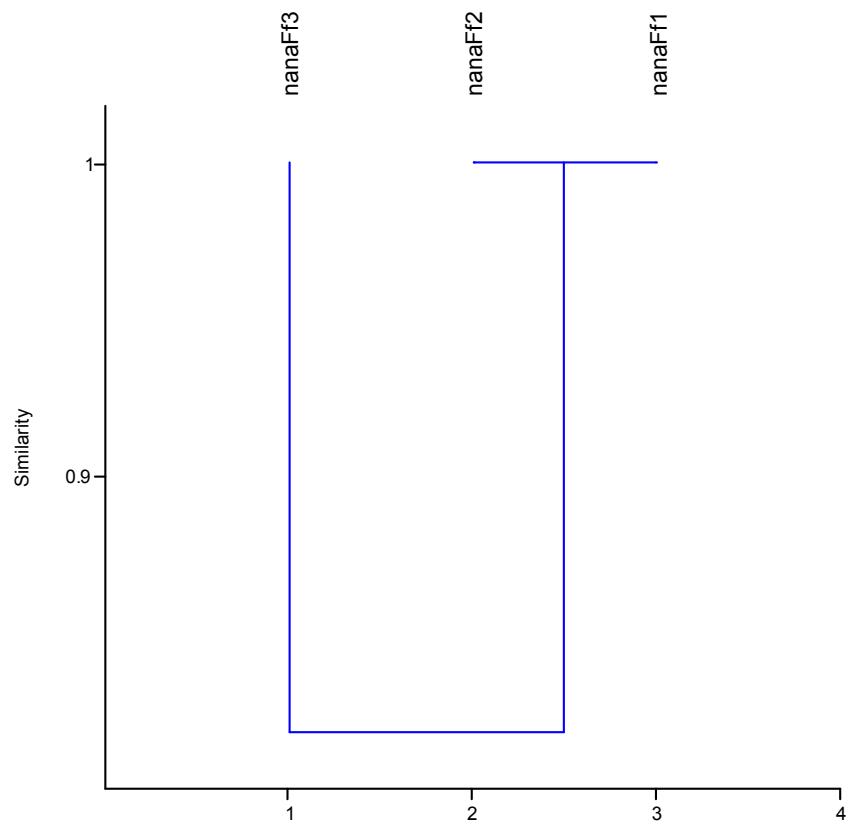

Fig. 3. The degree of similarity within nanaFf genotype. Blood samples collected from 10 males from nanaFf genotype and mixed together, then 3 samples were taken dendogram of similarty 


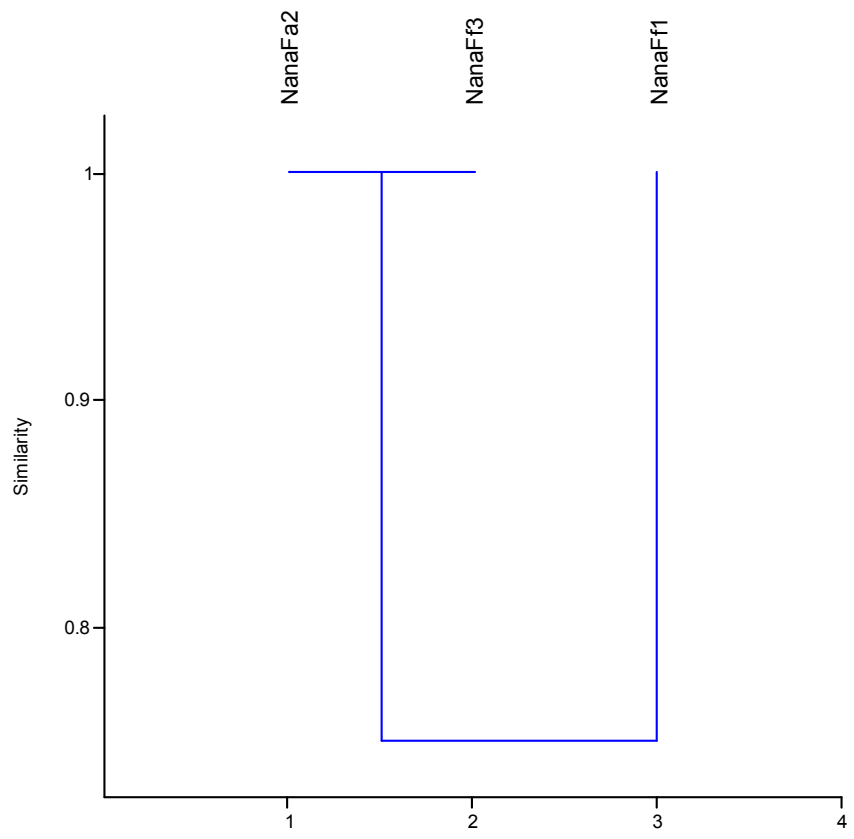

Fig .4. The degree of similarity within NanaFf genotype. Blood samples collected from 10 males from NanaFf genotype and mixed together, then 3 samples were taken dendogram of similarty

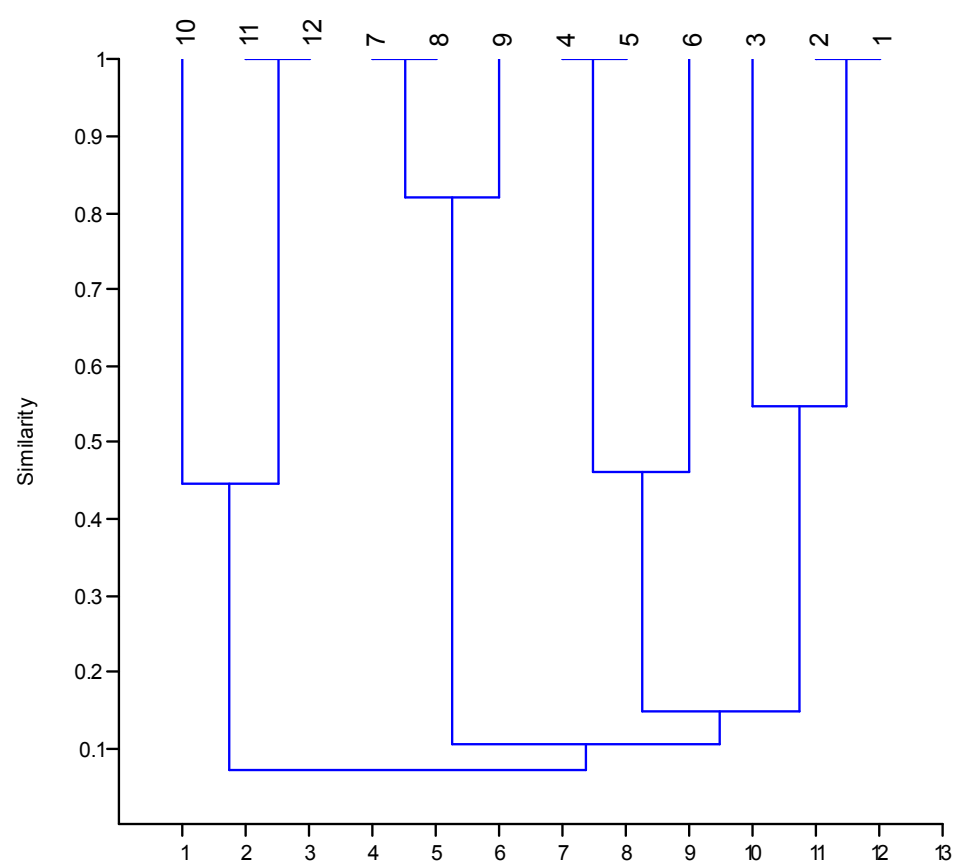

Fig. 5. Dendrogram the coefficient of genetic similarities between and within the different studied genotypes. Numbers 1,2 and 3 for genotypes nanaff, 4,5 and 6 for Nanaff; 7,8 and 9 for nanaFf and 10,11 and 12 for NanaFf

Although, the four genetic groups originated form the same genetic origin (normally feathered females (nanaff) with the semen of heterozygous naked neck frizzled males (NanaFf)), the similary within each genetic group reached $100 \%$, and that means that the diversity appears between genetic groups. Peters et al. (1998) achieved the same results on Nigeria local strains which carried the same genes (naked neck and frizzled). Olawumi and Ogunlade (2009) and Sola et al. (2013) stated that to achieve genetic improvement in Nigeria local strain, the first step should be studying its genetic diversity.

Polymorphism information for different genotypes provides an estimate of the similarity or diversity. However,we must keep it in mind to avoid the disadvantages of inbreeding. 


\section{CONCLUSION}

The naked neck gene had a great benefit in improving meat production, due to increasing breast muscle percentage and decreasing abdominal fat percent. Moreover, the naked neck gene improves heat tolerance of birds. The frizzled gene is playing a complementary role to increase acclimatization under the high heat circumstance. Also, it maximizes improvement in meat product. The degree of similarity or diversity within different genotypes reflects purity or identity of those genotypes. Although it must keep some variation within genotypes to avoid the disadvantage of inbreeding.

\section{REFERENCES}

Ajayi F.O., B.O. Agaviezor, P.K. Ajuogu, 2011. Semen characteristics of three strains of local cockerels in the humid tropical environment of Nigeria. International Journal of Animal Veterinary Advance 3: 125-127.

Alabi O.J., J. W. Ng'ambi, D. Norris, S.S.A. Egena,2012. Comparative study of three indigenous chicken breeds of South Africa: body weight and linear body measurements. Agriculture Journal 7: 220-225.

Berri C., E. Le Bihan-Duval, E. Baéza, Chartrin P., N. Millet and T. Bordeau, 2005. Effect of selection for or against abdominal fatness on muscle and meat characteristics of broilers. XVII th European Symposium on the Quality of Poultry Meat Doorwerth, The Netherlands, 23-26 May 2005,266-270.

Dorji N., S.K. Sunar, 2014. Morphometric variations among five Bhutanese indigenous chickens (Gallus domesticus). Journal of Animal and Poultry Sciences 3: 76-85.

Fathi M.M., A. Galal, S. EL-Safty, M. Mahrous, 2013. Naked neck and frizzle genes for improving chickens raised under high ambient temperature: I. Growth performance and egg production. World's Poultry Science Journal 69:813-832.

Haaren-Kiso A., P. Horst, A.V. Zàrate, 1994. Direct and indirect effects of the frizzle gene $(F)$ for the productive adaptability of layer hens. Animal Research Deve., 42: 98-114.

Hartl D.L., 1998. A primer for population genetics, 2nd ed. Sinauer Associates, Inc., Sunderland, MA. ISBN 0878933018.

Heyen D.W., J.I. Weller, M. Ron, M.B. Band, J.E. Beever, E. Feldmesser, Da Y., G.R. Wiggans, P.M. Van Raden and H.A. Lewin, 1999. A genome scan for QTL influencing milk production and health traits in dairy cattle. Physiology Genomics, 1: 165-175.

Hossain M.M., M. Nishibori, M.A. Islam, 2012. Meat yield from broilers, naked neck and full feathered chicken of Bangladesh. Agriculture 10: 55-67.
Kgwatalala P.M., A.M. Bolowe, K. Thutwa, S.J. Nsoso, 2013. Carcass traits of the naked-neck, dwarf and normal strains of indigenous Tswana chickens under an intensive management system. Agriculture Biology Journal N. Am. 4: 413-418.

Kgwatalala P.M., M. Nogayagae, S.J. Nsoso, 2012. Growth performance of different strains of indigenous Tswana chickens under intensive management system. African Journal Agriculture Research 7: 2438-2445.

Khalid A.M., I.A.Yousif, M.I. Omer, K.M. Elamin, 2012. Genetic variability of body composition traits in Sudanese Native large Beladi Chicken. Agriculuture Biology Journal North American 3: 69-76.

Liyanage R.P., C.M.B. Dematawewa, G.L.L.P. Silva, 2015. Comparative Study on Morphological and Morphometric Features of Village Chicken in Sri Lanka. Tropical Agriculture Research 26 : $261-$ 273.

Mahrous M.Y., L.M. Radwan, 2011. Impact of Naked Neck (NA) Gene, Sex and their Interaction on Live Growth Performance and Carcass Characteristics of Broiler Chicks under Summer Season of Egypt. Egypt. Poultry Science 31: 845853.

Matthew A.A., O.O. Sunday, O.N. Michael, I. Christian, M.B. Adeyemi, A.A. Olufunmilayo, 2011. Effect of crossbreeding on fertility, hatchability and embryonic mortality of nigerian local chickens. Tropical Animal Health production 44: 505510.

Mérat P., 1990. Major genes in fowls (Gallus gallus): genes other than those affecting size. Animal Production 3: 355-368.

Olawumi S.O., Ogunlade J.T., 2009. The effects of genotype and age of layer breeders on egg quality traits. Nigria Journal Animal Production 36: 228236.

Oni O. A., O. Olowofeso, C. O. N. Ikeobi, O. M. Sogunle, S. O. Durosaro and A. J. Sanda, 2016. Comparison of the Effectiveness of Decamer and Microsatellite Markers with Chicken Populations in Ogun and Ondo States, Nigeria. European International Journal of Science and Technology,5: 1-13.

Peters S.O., E.A. Omidiji, C.O.N. Ikeobi, M.O. Ozoje, O.A. Adebambo, 1998. Effects of naked neck and frizzled genes on egg traits fertility and hatchability in local chicken. Proc. Annual Conf. Animal Science Ass of Nigria (ASAN) Sept. 13th - 16th. Ebonyi State University Abakaliki, Nigeri. $262-264$.

Radwan L. M., A. E. El-Dlebshany, M.Y. Mahrous, 2014a. Determining genetic similarity and genetic diversity in selected Alexandria chickens using RAPD technique. Egypt. Poult. Sci. 34: 751-760.

Radwan L. M., A.E. El-Dlebshany, M.E. EL-Denary, 2014b. Microsatellite genetic differentiation analysis and organic matrix of eggshell in the 16th generation of chickens selected for egg 
production traits. Egyptian J. Anim. Prod. 51:4955.

Radwan L.M., M.Y. Mahrous, R.A.A. Younis, 2015. Immunity competence and some genetic aspects related to productive traits for five different genetic groups of chickens. Egyptian Poultry Science 35: $107-122$.

Rajkumar U., M.R. Reddy, S.V. Rao Rama, K. Radhika, M. Shanmugam, 2011. Evaluation of growth, carcass, immune response and stress parameters in naked neck chicken and their normal siblings under tropical winter and summer temperatures. Australian Journal Animal Science 24: 509-516.

Rohlf F.J., 1998. NTSYSpc Numerical Taxonomy and Multivariate Analysis System Version 2.0 User Guide. Applied Biostatistics Inc., Setauket, New York. 1998, 37 pp.
SAS Institute., 2013. JMP Version 11. User's Guide, SAS Institute Inc., Cary, NC.

Sola-Ojo F.E., K.L. Ayorinde, O.M. Jatto, A.A. Toye, 2013. Comparative Studies of Two Nigerian Ecotypes Chicken Kept in Battery Cages for Laying Performance and Egg Quality Traits. Asian Economical Soci. Soci. 3: 2224- 4433.

Thutwa K., S.J. Nsoso, P.M. Kgwatalala, J.C. Moreki, 2012. Comparative Live Weight, Growth Performance, Feed Intake, Carcass Traits and Meat Quality in Two Strains of Tswana Chickens Raised Under Intensive System in South East District of Botswana. Interntional Journal Applied Poultry Research 1: 21-26.

Zein El-Dein A., M. Zeiny, H. Ayoub, 1981. Carcass measurements of naked neck and normal chicks. Ann. Genetic Selection Animal 13: 433-440.

\footnotetext{
تحليل التنوع الوراثى ومقارنة الاداء الاتتاجى لبعض المجموعات الوراثية فى الدجاج. محمود يوسف محروس'، لمياء مصطفى رضوان'، مدحت العراقى الدينارى' 